University of Nebraska - Lincoln

DigitalCommons@University of Nebraska - Lincoln

\title{
Long-Term Prairie Falcon Population Changes in Relation to Prey Abundance, Weather, Land Uses, and Habitat Conditions
}

\author{
Karen Steenhof \\ USGS Forest and Rangeland Ecosystem Science Center \\ Michael Kochert \\ USGS Forest and Rangeland Ecosystem Science Center, mkocher1@unl.edu \\ Leslie B. Carpenter \\ Raptor Research Center, Boise State University, 970 Lusk Street, Boise, ID \\ Robert N. Lehman \\ USGS Forest and Rangeland Ecosystem Science Center
}

Follow this and additional works at: https://digitalcommons.unl.edu/usgsstaffpub

Part of the Earth Sciences Commons

Steenhof, Karen; Kochert, Michael; Carpenter, Leslie B.; and Lehman, Robert N., "Long-Term Prairie Falcon Population Changes in Relation to Prey Abundance, Weather, Land Uses, and Habitat Conditions" (1999). USGS Staff -- Published Research. 44.

https://digitalcommons.unl.edu/usgsstaffpub/44

This Article is brought to you for free and open access by the US Geological Survey at DigitalCommons@University of Nebraska - Lincoln. It has been accepted for inclusion in USGS Staff -- Published Research by an authorized administrator of DigitalCommons@University of Nebraska - Lincoln. 


\title{
LONG-TERM PRAIRIE FALCON POPULATION CHANGES IN RELATION TO PREY ABUNDANCE, WEATHER, LAND USES, AND HABITAT CONDITIONS ${ }^{1}$
}

\author{
Karen Steenhof and Michael N. Kochert \\ USGS Forest and Rangeland Ecosystem Science Center, Snake River Field Station, 970 Lusk Street, Boise, ID \\ 83706, e-mail: ksteenho@eagle.idbsu.edu \\ LESLIE B. CARPENTER \\ Raptor Research Center, Boise State University, 970 Lusk Street, Boise, ID 83706 \\ ROBERT N. LEHMAN \\ USGS Forest and Rangeland Ecosystem Science Center, Snake River Field Station, 970 Lusk Street, \\ Boise, ID 83706
}

\begin{abstract}
We studied a nesting population of Prairie Falcons (Falco mexicanus) in the Snake River Birds of Prey National Conservation Area (NCA) from 1974-1997 to identify factors that influence abundance and reproduction. Our sampling period included two major droughts and associated crashes in Townsend's ground squirrel (Spermophilus townsendii) populations. The number of Prairie Falcon pairs found on long-term survey segments declined significantly from 1976-1997. Early declines were most severe at the eastern end of the NCA, where fires and agriculture have changed native shrubsteppe habitat. More recent declines occurred in the portion of canyon near the Orchard Training Area (OTA), where the Idaho Army National Guard conducts artillery firing and tank maneuvers. Overall Prairie Falcon reproductive rates were tied closely to annual indexes of ground squirrel abundance, but precipitation before and during the breeding season was related inversely to some measures of reproduction. Most reproductive parameters showed no significant trends over time, but during the 1990s, nesting success and productivity were lower in the stretch of canyon near the OTA than in adjacent areas. Extensive shrub loss, by itself, did not explain the pattern of declines in abundance and reproduction that we observed. Recent military training activities likely have interacted with fire and livestock grazing to create less than favorable foraging opportunities for Prairie Falcons in a large part of the NCA. To maintain Prairie Falcon populations in the NCA, managers should suppress wildfires, restore native plant communities, and regulate potentially incompatible land uses.
\end{abstract}

Key words: Falco mexicanus, habitat, land uses, populations, Prairie Falcon, reproduction.

\section{INTRODUCTION}

Exceptionally high densities of nesting Prairie Falcons (Falco mexicanus) in the Snake River Canyon of southwestern Idaho were first recognized in the 1940s (M. Nelson, pers. comm.). In 1993, Congress established the Snake River Birds of Prey National Conservation Area (NCA) to protect 15 species of nesting raptors, of which the Prairie Falcon is most numerous (U.S. Dept. Interior 1979, 1995). Prairie Falcon nesting densities in the NCA are higher than in any other area reported in the literature, and it was once estimated that the NCA provided habitat for up to $5 \%$ of the species' nesting pairs (U.S. Dept. Interior 1979, Steenhof 1998).

\footnotetext{
'Received 15 April 1998. Accepted 12 October 1998.
}

Between 1979 and 1997, the NCA experienced extensive habitat change due to drought, wildfires, livestock grazing, and military training activity (Kochert and Pellant 1986, U.S. Dept. Interior 1996). Large areas of native shrub and perennial grass communities have been converted to homogeneous stands of non-native annual vegetation. These changes have affected distribution and abundance of Townsend's ground squirrels (Spermophilus townsendii; Van Horne et al. 1997), the primary prey species of Prairie Falcons in the NCA (Steenhof and Kochert 1988). Densities and reproductive success of many diurnal raptor species are closely related to the abundance of their prey (Smith and Murphy 1979, Smith et al. 1981, Korpimäki 1984). Weather, especially precipitation, also affects nesting success of some birds of prey (Olsen and 
Olsen 1989, Kostrzewa and Kostrzewa 1990, 1991), and weather sometimes interacts with prey availability to influence raptor reproduction (Steenhof et al. 1997). Few investigations, however, have collected adequate data to evaluate long-term population changes of predators in relation to prey and weather as well as anthropogenic disturbances. The purpose of this paper is to assess whether Prairie Falcon abundance, reproduction, and distribution in the NCA changed between 1974 and 1997, and to identify factors associated with population changes. We were particularly interested in whether Prairie Falcon nesting densities and reproduction were influenced by prey densities, precipitation, vegetation changes, livestock grazing, or military training activities.

\section{METHODS}

\section{STUDY AREA}

The study area included $2,430 \mathrm{~km}^{2}$ of public and private lands within the NCA in southwestern Idaho $\left(42^{\circ} 50^{\prime} \mathrm{N}, 115^{\circ} 50^{\prime} \mathrm{W}\right)$. Nesting surveys focused on a $130-\mathrm{km}$ stretch of the Snake River Canyon between Walters Ferry and Hammett (Fig. 1). Elevation of the canyon ranges from $700 \mathrm{~m}$ above sea level near the floor to $920 \mathrm{~m}$ at the canyon rim. Basalt cliffs range in height from 2 to $125 \mathrm{~m}$. Topography above the canyon is generally flat or slightly rolling with a few isolated buttes. Annual precipitation averages $15-25 \mathrm{~cm}$ and occurs mainly from November through April; summers are hot and dry. Native vegetation is characteristic of a shrubsteppe community with big sagebrush (Artemisia tridentata), shadscale (Atriplex confertifolia), and winterfat (Krascheninnicovia lanata) associations (U.S. Dept. Interior 1996). Livestock grazing occurs throughout the area. The Idaho Army National Guard conducts training maneuvers in the 56,000-ha Orchard Training Area (OTA) in the central part of the NCA (Fig. 1). The National Guard uses the OTA primarily for artillery firing, armored vehicle training, helicopter training, bivouacking, and small arms firing (U.S. Dept. Interior 1996).

We divided the NCA into $10-\mathrm{km}$ stretches of river and side-canyons to assess the distribution of Prairie Falcon pairs. We computed the amount of cliff area in each stretch from studies that interpreted aerial photographs using standard parallax methods and field verification measurements (Bentley and Hardyman, unpubl. data). We defined four different study strata in the NCA canyon (Fig. 1) based upon the potential for military training to affect cliff-nesting falcons: the west-central stratum, a $40-\mathrm{km}$ stretch of canyon immediately south of the OTA that encompassed radio-tagged pairs found in the OTA $\geq 30 \%$ of the time (Marzluff et al. 1997); the west stratum, an adjacent 20-km stretch of canyon southwest of the OTA; the east-central stratum, a 30-km stretch near C. J. Strike Reservoir, southeast of the OTA; and the 20-km east stratum near Hammett (Fig. 1).

\section{PRAIRIE FALCON ABUNDANCE}

We surveyed portions of the canyon to locate nesting pairs during 17 years from 1974-1997. We surveyed the entire Snake River Canyon and major side canyons within the NCA for Prairie Falcon nesting activity in eight years: 19761978 and 1990-1994, and we sampled certain stretches of canyon in nine additional years. From 1979-1984 and in 1997, we surveyed the north side of three segments of the canyon (Fig. 1). These "long-term survey segments" contained $18 \%$ of all known nesting areas in the west stratum, $61 \%$ of nesting areas in the westcentral stratum, and $38 \%$ of nesting areas in the east stratum.

Observers recorded nesting activity of Prairie Falcons and plotted nest locations on aerial photographs and 1:24,000-scale USGS topographic maps. We defined a historical nesting territory as any area of cliff where a Prairie Falcon pair was found in one or more years but where no more than one Prairie Falcon pair nested in the same year (Newton and Marquiss 1982). A nesting territory was considered occupied if we observed territorial defense, courtship, or other reproductive activity.

Methods in the 1970s and 1980s. From 19761988 , we systematically searched cliffs in the Snake River Canyon for Prairie Falcons throughout the nesting season. Observers walked along the rim of the canyon or below cliffs, stopping periodically to search for nests, and sometimes soliciting responses from territorial falcons by shouting, clapping hands, or tossing rocks from the cliff top. Incidental observations began in January each year, with systematic searches starting in March and continuing throughout the breeding season. We surveyed most canyon segments at least once dur- 
ing each stage of the nesting cycle (courtship, incubation, and brood rearing).

Methods in the 1990s. In 1990, we surveyed the canyon four times, attempting to duplicate the 1970 s walking surveys. For comparison, we also surveyed cliffs from observation points on the canyon floor. Results from walking and point surveys were similar in 1990, but point surveys were more efficient in locating pairs per unit effort (USGS, unpubl. data). From 1991-1997, we conducted surveys from observation points in standardized $1-\mathrm{km}$ segments of the canyon. Some side draws were surveyed by walking. Each point was surveyed for $2 \mathrm{hr}$ during each monthly survey. When a survey stretch was < $1 \mathrm{~km}$, survey time was proportionately less. Only one side of the canyon was surveyed from each observation point except where the canyon was very constricted. We conducted three full surveys each year from 1991-1994: one in March and early April, one in May, and one in June.

\section{PRAIRIE FALCON REPRODUCTION}

We assessed Prairie Falcon occupancy, nesting success, and productivity from a sample of nesting territories each year from 1974-1983, 19911994, and 1997. Before each nesting season, we identified at least 20 nesting territories known to have been occupied in earlier years. We tried to locate pairs at these "preselected" nesting territories during courtship, ascertain their breeding status during incubation, and observe them as often as needed to determine occupancy and nesting success. Some nests were entered and inspected for eggs, young, prey remains, or any sign of reproductive activity; others only were observed from a distance. From 1974-1978, the preselected sample included all territories identified by Ogden (1973) within a 72-km stretch of the NCA canyon. From 1979-1983, we selected a different set of nesting territories from throughout the NCA each year, using stratified random sampling with proportional allocation according to falcon abundance in canyon stretches. We pooled data from radio-tagged and control pairs because radios did not influence Prairie Falcon reproduction (Vekasy et al. 1996).

In all years we confirmed laying if an occupied nesting territory contained an incubating adult, eggs, young, or any other indication that eggs were laid (e.g., fresh eggshell fragments in fresh nesting material). In the 1990 s, we also classified pairs as "laying" if an adult entered a cavity and remained within the cavity for $\geq 1$ $\mathrm{hr}$ during the incubation period. In all years, we considered laying pairs successful if $\geq 1$ young reached 30 days of age (Steenhof 1987). We used a photographic aging-key (Moritsch 1983) to age young during nest climbs and remote observations. Median hatch dates for broods were calculated by backdating from estimated ages of young.

To ensure that productivity comparisons among years were not biased by researcher manipulations, we excluded nesting attempts where nest site enhancements, manipulations of eggs or young, or disease treatment occurred. We also excluded information from five nesting attempts where investigators caused egg or chick mortality. Analyses of percent of pairs successful were based on pairs selected for study prior to each nesting season. The analysis of percent of laying pairs successful included any pairs with nesting attempts confirmed during incubation and known outcomes (Steenhof and Kochert 1982). Brood size at fledging was the mean number of young in nests where $\geq 1$ young reached 30 days of age, and was based on all successful pairs for which complete counts were obtained. To estimate number fledged per pair and per laying pair, we multiplied percent success and brood size at fledging (Steenhof and Kochert 1982).

\section{GROUND SQUIRREL ABUNDANCE}

We used data from live trapping grids to estimate relative yearly abundance of Townsend's ground squirrels in the NCA. For 1975-1982, we used estimated densities of adult squirrels based on unpublished data collected by Smith and Johnson (1985) and Johnson et al. (1987). Juvenile densities from 1975-1982 were calculated using the no recruitment special case of the Jolly-Seber model for open populations, as described by Van Horne et al. (1997). For 19901994, we used adult and juvenile densities reported by Van Horne et al. (1997).

\section{LAND USES AND HABITAT CONDITIONS}

We assessed habitat conditions in the predicted foraging areas of falcons from each of the four canyon strata (Fig. 1) on a Geographic Information System using data collected by other investigators. Predicted foraging areas were based on home ranges determined by radio telemetry 


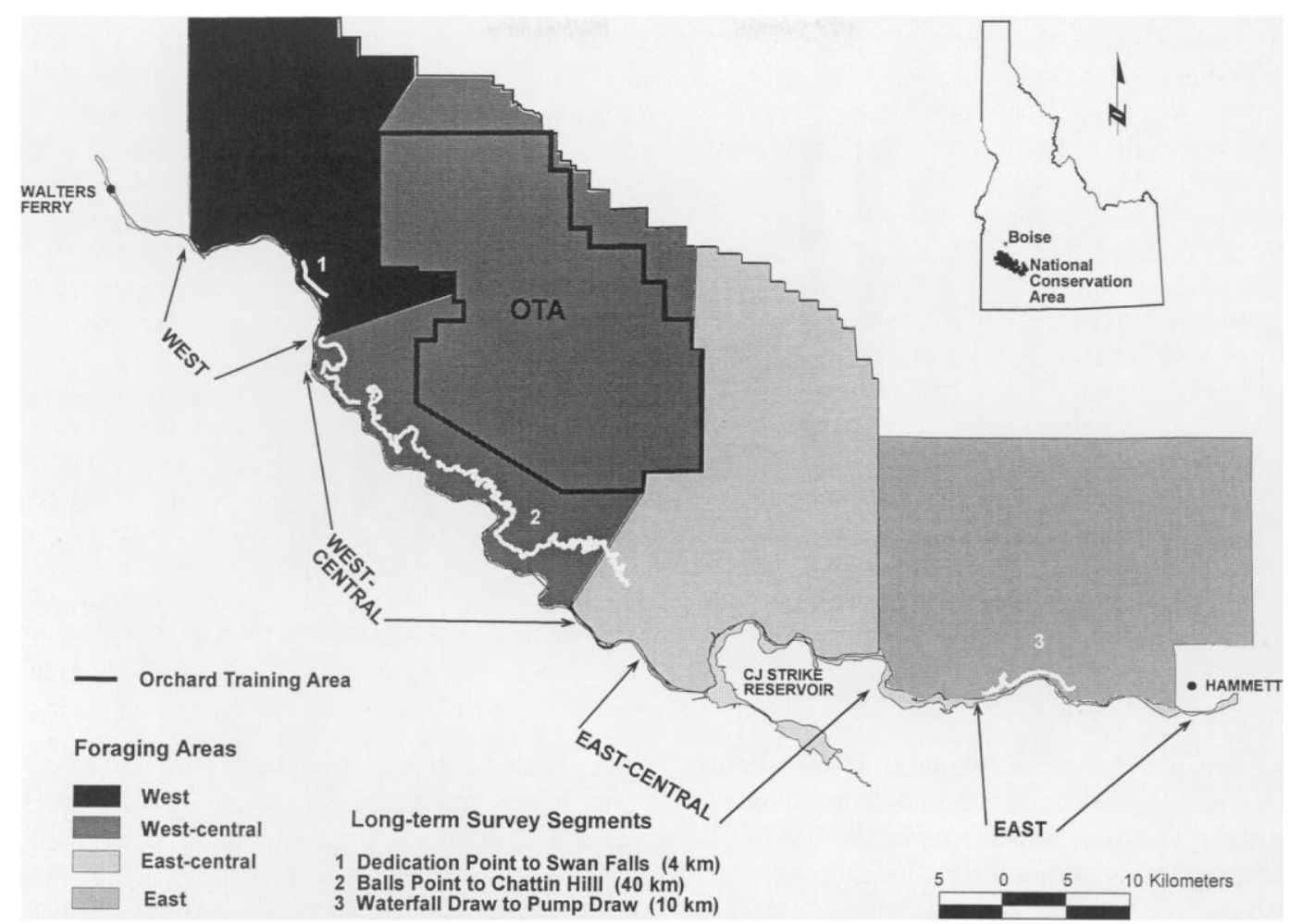

FIGURE 1. Location of the Orchard Training Area, standardized survey segments, canyon strata, and associated foraging areas in and near the Snake River Birds of Prey National Conservation Area.

(Dunstan et al. 1978, Marzluff et al. 1997). Prairie Falcons in the NCA foraged over large (mean $=300 \mathrm{~km}^{2}$ ), undefended areas extending up to $22 \mathrm{~km}$ north of the canyon (Marzluff et al. 1997).

We assessed habitat change in each stratum by comparing a 1979 vegetation map, developed through visual interpretation and field verification of low level aerial photographs (U.S. Dept. Interior 1979), to a 1994 vegetation map, which was based on supervised classification of Landsat thematic mapper satellite imagery (Knick et al. 1997). We assessed shrub loss from 1994 to 1997 from Bureau of Land Management and Idaho Army National Guard maps that depicted boundaries of fires that occurred from 19941996.

We assessed livestock grazing intensity in the same four strata from S. T. Knick and S. E. Watts' unpublished counts of cattle and sheep fecal material on 485 randomly selected transects (USGS, unpubl. data). From 1991-1994, observers classified fecal matter of each species as present or absent on four segments of each transect. The sum of the scores gave each transect a grazing intensity score of 0 (absent), 1 (low), 2 (medium low), 3 (medium high), or 4 (high). We tabulated the percent of transects in each stratum that had signs of livestock use and calculated the mean grazing intensity score for transects within each stratum that had signs of livestock use. We categorized Townsend's ground squirrel habitat potential as low or high on transects within each stratum, based on the amount of native perennial grass cover $(<$ or $>$ 5\%, respectively; U.S. Dept. Interior 1996) on 589 sites sampled by S. T. Knick and S. E. Watts (unpubl. data) from 1991-1994.

\section{STATISTICAL ANALYSES}

We used SYSTAT (SPSS Inc. 1997) and STATXACT (Cytel Software 1989) for statistical analyses. Significance was evaluated at $P=0.05$. We used precipitation data from the Boise Airport weather station for all weather analyses. We used Kruskal-Wallis tests to compare initial nest- 


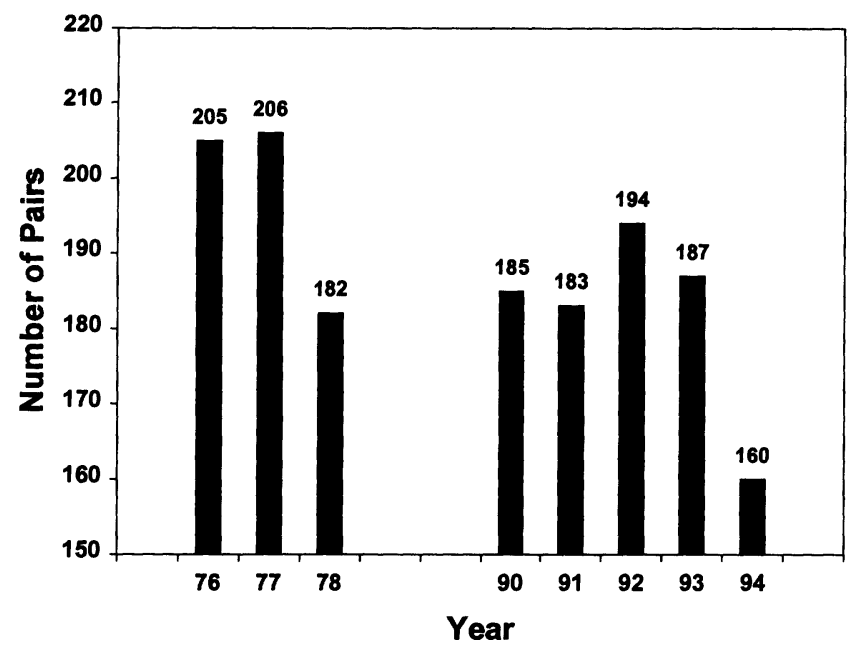

FIGURE 2. Number of Prairie Falcon pairs in the Snake River Birds of Prey National Conservation Area in the eight years that full surveys were conducted.

ing densities by strata. We used Mann-Whitney tests to assess differences in falcon abundance in the 1970s and 1980s versus the 1990s. We assessed trends through time by running simple correlations between year and selected variables. We used two-factor (year and strata) log-linear models to test for differences in occupancy and success rates. We used two-factor (year and strata) analyses of variance to assess differences in brood size at fledging with hatch date as a covariate. Relationships between ground squirrel abundance, precipitation, and falcon reproduction and abundance were assessed by simple correlation and multiple regression analyses. We used log-likelihood $G$-tests to compare proportions of transects with sheep and cattle use by strata. We transformed cattle and sheep grazing intensity scores using a square-root function and compared scores among strata using analysis of variance with Bonferroni adjusted paired contrasts.

\section{RESULTS}

\section{PRAIRIE FALCON DISTRIBUTION IN THE 1970S}

Prairie Falcons were not evenly distributed throughout the NCA when surveys began in 1976. From 1976-1978, number of pairs per kilometer of river varied significantly (KruskalWallis $H_{3}=8.3, P=0.04$ ) among strata. Number of pairs per kilometer was highest in the west stratum (mean $=3.28$ pairs $\mathrm{km}^{-1}$ ) where cliffs are highest and where falcon pairs some- times nested within $50 \mathrm{~m}$ of each other. Numbers were lowest in the east stratum $\left(0.8\right.$ pairs $\left.\mathrm{km}^{-1}\right)$ and intermediate in the east-central (1.29 pairs $\mathrm{km}^{-1}$ ) and west-central (1.61 pairs $\left.\mathrm{km}^{-1}\right)$ strata. From 1976 to 1978, distances between nearest adjacent pairs averaged $646 \mathrm{~m}$.

The amount of cliff surface area explained $91 \%$ of variation in number of falcon pairs per $10-\mathrm{km}$ survey stretch in $1976(P<0.001)$. Number of pairs $\mathrm{km}^{-2}$ of cliff also varied significantly by strata (Kruskal-Wallis $H_{3}=10.5$, $P=0.02$ ) in the 1970 s. When assessed in relation to amount of cliff area available, nesting densities were highest in the west-central stratum $\left(\right.$ mean $=45.8$ pairs $\mathrm{km}^{-2}$ ), nearly as high in the west stratum (39.7 pairs $\mathrm{km}^{-2}$ ), and much lower in the east (35.4 pairs km${ }^{-2}$ ) and east-central (34.7 pairs $\mathrm{km}^{-2}$ ) strata.

\section{CHANGES IN PRAIRIE FALCON ABUNDANCE}

Total number of Prairie Falcon pairs nesting in the NCA ranged from 160 to 206 in the eight years that full surveys were conducted (Fig. 2). Mean number of pairs in the early survey years (1976-1978) did not differ from the mean number in 1990-1994 (Mann-Whitney $U=11.0, P$ $=0.30$ ); although not significant, correlation analyses suggested an overall decline in number of pairs through time ( $r=-0.64, n=8, P=0.09$ ). Number of pairs was highest during the first two years of complete surveys, but numbers declined in 1978. Number of pairs found in 1990 was just 


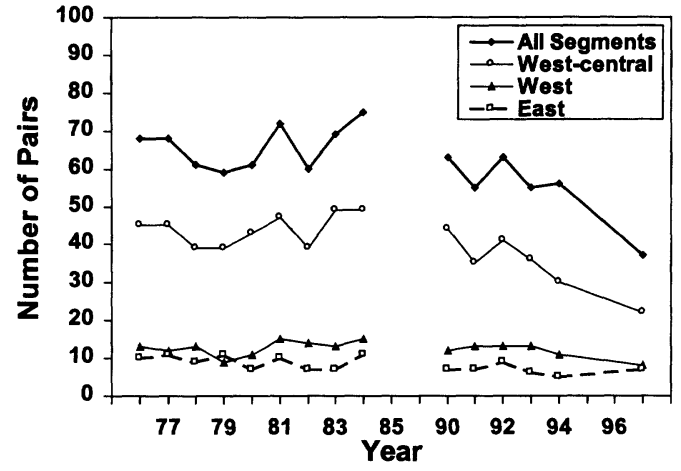

FIGURE 3. Number of Prairie Falcon pairs in longterm survey segments within the Snake River Birds of Prey National Conservation Area, 1976-1997.

slightly higher than that found in 1978. In 1994, we identified only 160 Prairie Falcon pairs in the NCA, fewer than in any year that complete surveys of the area were conducted. Declines occurred in many of the $10-\mathrm{km}$ stretches we surveyed. By 1994, 7 of 19 10-km stretches had Prairie Falcon densities below levels recorded from 1976-1978, and 12 stretches were unchanged from 1976-1978 levels. No stretches of canyon had more pairs than observed from 1976-1978.

Number of pairs in the three long-term survey segments correlated closely with number of pairs in the entire study area in years when full surveys were conducted $(r=0.93, n=8, P=$ 0.001 ). From 1976-1997, number of falcon pairs nesting in the three long-term survey segments declined significantly $(r=-0.66, n=15, P=$ 0.007). In 1997, the 37 pairs in these stretches represented a $46 \%$ decline from the 1976 level of 68 , and a $51 \%$ decline from the peak count of 75 recorded in 1984 (Fig. 3). The decline in number of pairs on the three long-term survey segments occurred mainly in the west-central segment $(r=-0.65, n=15, P=0.009)$. Populations in the west survey segment showed no significant change $(r=-0.25, n=15, P=$ 0.37). A small, but long-term decline was significant in the east segment, even though numbers in the east increased from 1994 to 1997 ( $r$ $=-0.66, n=15, P=0.008$ ).

During the 1990s, Prairie Falcons occupied $37-68 \%$ of the historical territories we sampled each year (mean $\pm \mathrm{SD}=57 \pm 12 \%, n=5$ ). Occupancy rates differed significantly with both year $\left(\chi_{4}^{2}=55.8, P<0.001\right)$ and strata $\left(\chi^{2}{ }_{3}=\right.$
315.2, $P<0.001)$. Occupancy rates declined significantly during the 1990s $(r=-0.96, n=$ $5, P=0.01)$; they were highest in $1992(68 \%)$ and lowest in 1997 when pairs occupied only $37 \%$ of traditional territories. Mean occupancy rates during the 1990s were highest in the west $(73 \%)$ and east-central $(67 \%)$ strata and lowest in the east $(47 \%)$ and west-central $(51 \%)$ strata. Occupancy rates in the west-central stratum declined from 1992 to 1997 , whereas rates in the east stratum were above average in 1997 (64\%).

\section{PRAIRIE FALCON REPRODUCTION}

From 1974-1997, an average of $63 \%$ of all Prairie Falcon pairs successfully raised young, and an average of $70 \%$ of laying pairs were successful (Table 1). Success rates showed no significant trends over time $(r=-0.205, n=15$, $P=0.46$ for all pairs; $r=0.007, n=22, P=$ 0.98 for laying pairs). Successful pairs fledged an average of 3.9 young for all years; mean brood size at fledging increased slightly but significantly from 1974-1997 ( $r=0.46, n=22, P$ $=0.03$ ). From 1991-1997, mean brood size at fledging (4.19) was significantly higher $\left(t_{12.7}=\right.$ $-4.64, P<0.001)$ than from 1974-1983 (3.76). Overall productivity averaged 2.46 young per pair from 1974-1997 (Table 1). The median productivity rate over the same time period (2.42) exceeded the median replacement standard of 2 young per pair that Runde (1987) calculated was necessary to maintain a Prairie Falcon population through time. Number of young per pair showed no significant trends over time $(r=$ $-0.02, n=15, P=0.93$ ).

\section{PRAIRIE FALCON-GROUND SQUIRREL RELATIONSHIPS}

Ground squirrel numbers were relatively high when studies began in 1975 and 1976 (Fig. 4). A winter drought prior to the 1977 breeding season caused squirrels to suspend reproduction in 1977 and enter torpor 4-6 weeks earlier than usual (Smith and Johnson 1985). Densities were low in 1978 due to the absence of a yearling cohort. Numbers recovered slowly from 19791982 (Fig. 4). In 1991, ground squirrel abundance was higher than in the 1970 s, and it increased to a peak level of 24.5 squirrels $\mathrm{ha}^{-1}$ in 1992. A spring 1992 drought followed by a severe winter in 1992-1993 affected overwinter survival and drastically reduced ground squirrel abundance in 1993 and 1994 (Van Horne et al. 
TABLE 1. Nesting success and productivity of Prairie Falcons in the Snake River Birds of Prey National Conservation Area, 1974-1997. Sample sizes are in parentheses.

\begin{tabular}{|c|c|c|c|c|c|c|}
\hline Year & $\begin{array}{l}\% \text { of pairs } \\
\text { successful }\end{array}$ & $\begin{array}{l}\text { \% of laying pairs } \\
\text { successful }\end{array}$ & $\begin{array}{l}\text { Brood size at } \\
\text { fledging }\end{array}$ & $\begin{array}{l}\text { No. fledged/ } \\
\text { laying pair }\end{array}$ & $\begin{array}{l}\text { No. fledged/ } \\
\text { pair }^{b}\end{array}$ & $\begin{array}{r}\text { Total } \\
\text { fledged }\end{array}$ \\
\hline 1974 & $69(16)$ & 64 (11) & 3.94 (17) & 2.52 & 2.72 & \\
\hline 1975 & $76(25)$ & 86 (22) & $3.76(29)$ & 3.23 & 2.86 & \\
\hline 1976 & 75 (24) & $81(31)$ & $3.98(43)$ & 3.22 & 2.99 & 613 \\
\hline 1977 & $55(20)$ & $67(33)$ & 3.64 (33) & 2.44 & 2.00 & 412 \\
\hline 1978 & $50(28)$ & $18(35)$ & $3.67(30)$ & 0.66 & 1.84 & 335 \\
\hline 1979 & $65(43)$ & 75 (32) & $3.73(30)$ & 2.80 & 2.42 & \\
\hline 1980 & $56(52)$ & 65 (54) & $4.03(36)$ & 2.62 & 2.26 & \\
\hline 1981 & $80(51)$ & 83 (46) & $4.05(22)$ & 3.36 & 3.24 & \\
\hline 1982 & $41(29)$ & 69 (26) & 3.53 (17) & 2.44 & 1.45 & \\
\hline 1983 & $71(31)$ & 73 (26) & 3.24 (17) & 2.37 & 2.30 & \\
\hline 1984 & -- & 88 (16) & 3.95 (19) & 3.48 & - & \\
\hline 1985 & -- & 93 (14) & 4.08 (13) & 3.79 & - & \\
\hline 1986 & -- & 44 (18) & $3.43(7)$ & 1.51 & - & \\
\hline 1987 & -- & 70 (37) & $4.32(31)$ & 3.02 & - & \\
\hline 1988 & -- & $75(8)$ & $3.86(7)$ & 2.90 & - & \\
\hline 1989 & -- & $83(6)$ & $3.67(6)$ & 3.05 & - & \\
\hline 1990 & -- & $68(41)$ & $4.06(33)$ & 2.76 & - & \\
\hline 1991 & $78(68)$ & 89 (37) & $4.08(49)$ & 3.63 & 3.18 & 582 \\
\hline 1992 & $79(85)$ & $86(64)$ & $4.23(53)$ & 3.64 & 3.34 & 648 \\
\hline 1993 & $37(91)$ & 47 (53) & $4.14(37)$ & 1.95 & 1.53 & 286 \\
\hline 1994 & $61(83)$ & $69(58)$ & 4.34 (44) & 2.99 & 2.65 & 424 \\
\hline 1997 & $51(37)$ & $56(27)$ & 4.14 (14) & 2.30 & 2.11 & \\
\hline $\bar{x} \pm$ SD all years & $63 \pm 14$ & $70 \pm 17$ & $3.90 \pm 0.29$ & $2.76 \pm 0.74$ & $2.46 \pm 0.61$ & \\
\hline
\end{tabular}

a Calculated as the product of $\%$ of laying pairs successful and brood size at fledging.

b Calculated as the product of \% of pairs successful and brood size at fledging. Data are not available for 1984-1990 because Prairie Falcon pairs were not preselected in those years.

c Data available only for years with complete counts of pairs for the entire area.

1997). In 1997, transect sampling in portions of the NCA, coupled with subjective observations, suggested that overall squirrel populations had increased from 1994 levels.

Most measures of Prairie Falcon reproduction correlated positively with estimated ground squirrel abundance (Table 2). From 1976-1994, total number of Prairie Falcons fledged from the

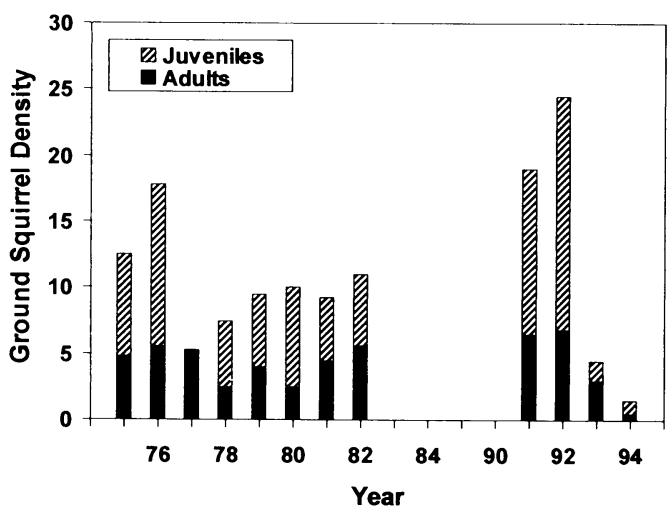

FIGURE 4. Estimated densities of Townsend's ground squirrels $\left(n \mathrm{ha}^{-1}\right)$ in the NCA, 1975-1994.
NCA correlated strongly $(P \mathrm{~s}<0.01)$ with both juvenile and overall ground squirrel density. Total number of young fledged from the long-term survey segments, which was based on four additional years, also correlated significantly and positively with juvenile and overall squirrel densities $(P s<0.05)$. We also found significant correlations $(P s<0.05)$ between both percent of falcon pairs successful and number of falcons fledged per pair and juvenile and overall squirrel densities. Number fledged per laying pair correlated significantly only with overall squirrel densities, and percent of laying pairs successful correlated significantly only with adult squirrel densities. Three variables (brood size at fledging, total pairs, and pairs in the long-term survey segments) did not correlate significantly with any of the measures of ground squirrel abundance, but number of pairs was more closely related to adult squirrel abundance $(P=0.08)$ than to juvenile or overall squirrel abundance $(P s>0.38)$. We found no relationship between number of nesting pairs and ground squirrel abundance in the previous year $(r=0.56, n=$ $6, P=0.25$ ). 
TABLE 2. Correlation coefficients between estimated Townsend's ground squirrel abundance and measures of Prairie Falcon reproduction in the Snake River Birds of Prey National Conservation Area, 1975-1994.

\begin{tabular}{|c|c|c|c|c|}
\hline \multirow[b]{2}{*}{ Prairie Falcons } & \multirow[b]{2}{*}{$n$} & \multicolumn{3}{|c|}{ Ground squirrel density } \\
\hline & & Adult & Juvenile & Total \\
\hline Number of nesting pairs & 7 & 0.70 & 0.28 & 0.39 \\
\hline \multicolumn{5}{|l|}{ Number of pairs in the long-term } \\
\hline survey segments & 11 & 0.52 & 0.23 & 0.32 \\
\hline Percent of pairs successful & 12 & 0.44 & $0.65^{*}$ & $0.64 *$ \\
\hline Percent of laying pairs successful & 12 & $0.57 *$ & 0.51 & 0.56 \\
\hline Number fledged per laying pair & 12 & 0.50 & 0.55 & $0.57 *$ \\
\hline Brood size at fledging & 12 & -0.20 & 0.25 & 0.14 \\
\hline Number fledged per pair & 12 & 0.37 & $0.66^{*}$ & $0.63 *$ \\
\hline Total number fledged & 7 & $0.75^{*}$ & $0.88^{* *}$ & $0.89 * *$ \\
\hline \multicolumn{5}{|l|}{ Number fledged in the long-term } \\
\hline survey segments & 11 & 0.49 & $0.63 *$ & $0.64 *$ \\
\hline
\end{tabular}

${ }^{*} P<0.05,{ }^{* *} P<0.01$.

Two measures of Prairie Falcon reproduction that did not correlate strongly with ground squirrel numbers were related inversely to the amount of precipitation prior to and during the onset of the breeding season. Brood size at fledging and number fledged per laying pair correlated inversely with total precipitation from November to April ( $r=-0.49$ and -0.51 , respectively, $n$ $=22, P=0.02)$ and also from February through April $(r=-0.52$ and -0.43 , respectively, $P=$ 0.01 and 0.05 , respectively), but not with precipitation from April through June (Ps $>0.56)$. None of the other measures of falcon reproduction was related to precipitation $(P s>0.06)$, and precipitation did not explain a significant portion

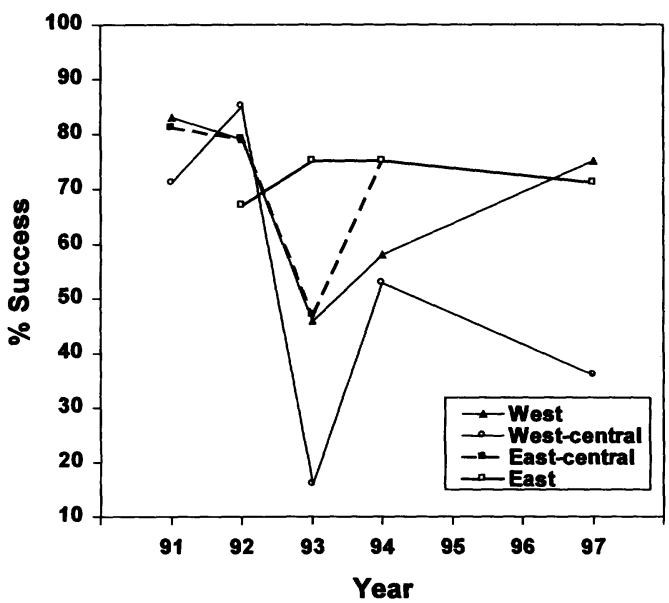

FIGURE 5. Annual Prairie Falcon nesting success rates in four strata within the Snake River Birds of Prey National Conservation Area, 1991-1997. The east-central stratum was not sampled in 1997. of the variation in these measures when we considered squirrel abundance and weather together in multiple regressions $(P s>0.10)$.

\section{SPATIAL VARIATION IN FALCON REPRODUCTION}

During the 1990s, nesting success of Prairie Falcon pairs varied significantly among study strata $\left(\chi_{3}^{2}=97.8, P<0.001\right)$ and years $\left(\chi_{4}^{2}=30.0\right.$, $P<0.001)$. After the 1992 drought, nesting success dropped sharply in the west-central stratum, much smaller declines occurred in the west and east-central strata, and success rates in the east showed no change (Fig. 5). In 1997, the success rate in the west stratum rebounded from 1994 levels, but the rate in the west-central stratum declined. Until 1991, we did not have adequate sample sizes to analyze success by strata by year. However, when we pooled data within our three sampling periods (1974-1983, 1991-1994, and 1997), we found that success rates in the west-central stratum declined significantly with time $\left(G_{2}=10.2, P=0.006\right.$; Fig. 6$)$; rates in the east and west strata were unchanged $\left(G_{2}=\right.$ $0.006, P=0.99$ and $G_{2}=0.97, P=0.62$, respectively).

Mean brood size at fledging did not vary significantly by strata during the 1990s $\left(F_{3,185}=\right.$ $1.0, P=0.38$ ). Hatch date was a significant covariate in the analysis of brood size at fledging $\left(F_{1,182}=21.7, P<0.001\right)$ with smaller broods being more common late in the nesting season. Number of young fledged per pair fell below the minimum replacement standard of 2 (Runde 1987) in 1993 and 1997 in the west-central stratum, and in 1993 in the east-central stratum, but 


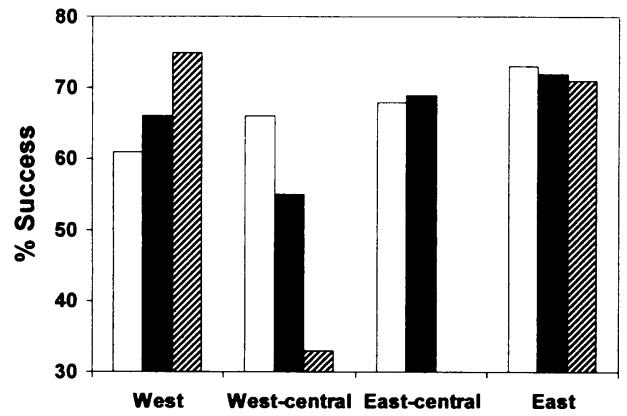

FIGURE 6. Percent of Prairie Falcon pairs successful in four study strata and three time periods in the Snake River Birds of Prey National Conservation Area. Open bars represent 1974-1983, black bars represent 19911994, and hatched bars represent 1997. The east-central stratum was not sampled in 1997.

overall differences were not significant among strata from 1991-1997 $\left(F_{3,14}=1.0, P=0.42\right)$.

\section{HABITAT CONDITIONS AND LAND USES}

Habitat alteration occurred in all strata and in all years of our study, but its intensity, distribution, and timing varied (Fig. 7). By 1979, fires and agriculture already had fragmented habitat in the east stratum to a much greater extent than in the other strata. Thirty-five percent of the east stratum was grassland in 1979, compared to only $15-18 \%$ of the other strata. In addition, $27 \%$ of the east stratum was farmed, compared to only
$4 \%$ in the west-central, $18 \%$ in the east-central, and $22 \%$ in the west strata. By 1979 , the proportion of the east stratum in shrubs was approximately half that of the other strata (Fig. 7).

Between 1979 and 1994, the nature and distribution of habitat change differed from that before 1979. Less than $2 \%$ of the native rangeland within Prairie Falcon foraging ranges was converted to agriculture between 1979 and 1994 . Fires, on the other hand, caused extensive shrub loss, primarily between 1981 and 1985 (Kochert and Pellant 1986). Most shrub loss between 1979 and 1994 occurred in the east-central and west-central strata (Fig. 7). By 1994, fires and agriculture had left only 4-35\% of the habitat in each stratum in shrubs (Fig 7). From 19941996, fires consumed an additional 38,700 ha, primarily in the west stratum. Most fires that occurred from 1994-1996 in the west-central and east-central strata were in previously burned areas, so there was little loss of additional shrublands. By 1997, native shrub habitat comprised only $4-28 \%$ of the area in each stratum. The west-central stratum still had the highest percent shrub cover, even though it sustained extensive shrub losses between 1979 and 1994 (Fig 7).

Ground squirrel habitat potential, as measured by the amount of native perennial grass cover in 1991-1994, differed significantly by strata $\left(G_{3}\right.$ $=70.8, P<0.001)$. More transects had high

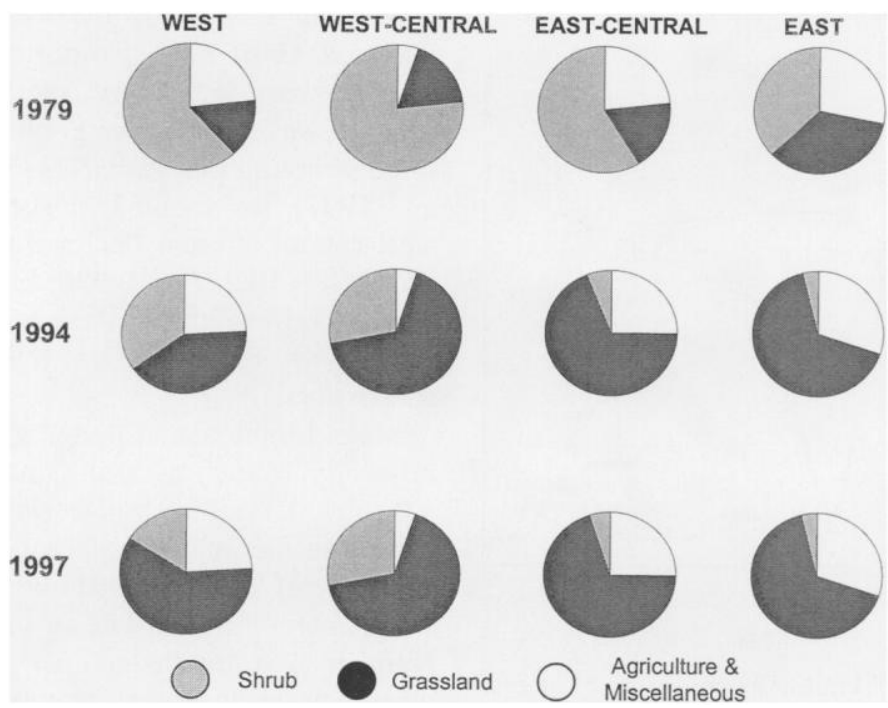

FIGURE 7. Percent of Prairie Falcon foraging areas composed of shrub, grass, agricultural and other habitats in four strata, 1979-1997. 
ground squirrel habitat potential in the west $(66 \%)$ and west-central $(58 \%)$ strata than the east $(20 \%)$ and east-central $(26 \%)$ strata $\left(G_{1}=\right.$ 67.3, $P<0.001)$.

Military training occurred only in the westcentral stratum. Livestock grazing occurred throughout the area, but the proportion of sites with signs of livestock use varied significantly among strata for both cattle $\left(G_{3}=10.1, P=\right.$ $0.02)$ and sheep $\left(G_{3}=19.2, P<0.001\right)$. The east stratum had significantly more sites used by cattle and significantly fewer sites used by sheep. The proportion of sites with cattle $\left(G_{2}=\right.$ 1.3, $P=0.52)$ and sheep $\left(G_{2}=1.7, P=0.42\right)$ was similar in the three westernmost strata. Grazing intensity scores at used sites varied significantly among strata for cattle $\left(F_{3,423}=3.4, P\right.$ $=0.02)$, but not for sheep $\left(F_{3,102}=1.8, P=\right.$ $0.15)$. Cattle use was significantly higher in the east than in the west stratum (pairwise comparison with Bonferroni adjustment, $P=0.01$ ); cattle use in the west-central and east-central strata was intermediate and did not differ significantly from the other strata $(P \mathrm{~s}>0.21)$.

\section{DISCUSSION}

\section{PREY ABUNDANCE}

Our long-term data on yearly variation in nesting success and productivity support earlier conclusions (U.S. Dept. Interior 1979) that Prairie Falcon reproduction in the NCA is closely tied to ground squirrel abundance. Overall falcon reproduction in the NCA showed no significant trends through time. Instead it varied among years, as ground squirrel populations responded to two significant droughts. Ground squirrels have been and continue to be the single most important prey species for Prairie Falcons in the NCA (Steenhof and Kochert 1988, Holthuijzen 1990, Marzluff et al. 1997). Steenhof and Kochert (1988) demonstrated that Prairie Falcons in the NCA were dietary specialists. Prairie Falcons showed strong preferences for Townsend's ground squirrels even when squirrels were rare, and falcons had no single important alternate prey species in the NCA during a 7-year investigation (Steenhof and Kochert 1988). Ground squirrels contain a high amount of fat and provide more kilocalories per gram than alternative prey species (U.S. Dept. Interior 1979). Ground squirrel abundance during the breeding season appeared to influence the percent of falcon pairs that were successful, number of young fledged per pair, and total number of young fledged. Prairie falcon reproduction was best predicted by juvenile ground squirrel densities or by a combination of juvenile and adult densities. Number of falcon nesting pairs, on the other hand, was not related to juvenile ground squirrel abundance and only weakly related to abundance of adult squirrels. Galushin (1974) predicted that if migratory raptors find scarce food when they return to previous nesting areas, they may leave to find better nesting conditions elsewhere.

\section{WEATHER}

Extreme droughts affected Prairie Falcons twice during the 24-year study period. Prairie falcon nesting success and productivity declined as ground squirrel populations declined after a winter drought in 1976-1977 (Smith and Johnson 1985) and after a spring drought in 1992 (Van Horne et al. 1997). In contrast to other raptors (Olsen and Olsen 1989, Kostrzewa and Kostrzewa 1990), long-term reproductive rates of Prairie Falcons were not related to spring precipitation during the brood-rearing period. However, brood sizes at fledging were related inversely to the amount of precipitation prior to and during the onset of the breeding season. Successful Prairie Falcons produced large broods in dry years and smaller broods in wet years. Precipitation prior to the nesting season usually increases the amount of grass and weed cover in the NCA and may interfere with the ability of Prairie Falcons to find and secure prey. Bechard (1982) found that vegetative cover limited the accessibility of prey to Swainson's Hawks (Buteo swainsoni). Decreased foraging efficiency associated with tall vegetative cover late in the nesting season could affect Prairie Falcons by lowering the number of young that successful pairs can support. Precipitation during winter and early spring also could enhance conditions for nest parasites and therefore decrease nestling survival; McFadzen and Marzluff (1996) reported more nestling mortality due to infestations of hematophagous ectoparasites (Haematosiphon inodurus) in Prairie Falcon nests within the NCA during the wet spring of 1993 than during the dry spring of 1992.

\section{HABITAT CONDITIONS AND LAND USE}

Long-term Prairie Falcon population declines may be related to extensive shrub loss that has 
occurred in the NCA. Although Townsend's ground squirrel abundance is closely tied to the amount of native perennial grass cover, ground squirrels also rely on shrubs (U.S. Dept. Interior 1996). Adult ground squirrels ate new growth of sagebrush, and juveniles ate primarily winterfat during drought years (Van Horne et al. 1998). Ground squirrels in burned areas dominated by non-native annual grasses are more vulnerable to fluctuations in food biomass and diversity; populations in annual grasslands devoid of shrub cover show wider annual fluctuations (Yensen et al. 1992, Van Horne et al. 1997). Optimal ground squirrel habitat likely consists of native perennial grasslands interspersed with shrub cover (U.S. Dept. Interior 1996).

Early declines in number of Prairie Falcon pairs nesting at the eastern end of the NCA may have been associated with habitat fragmentation caused by fires and agricultural development that occurred before our study began. Habitat patterns we measured, however, did not explain recent declines in both abundance and reproduction of Prairie Falcons in the west-central stratum. Ground squirrel habitat potential, as measured by the amount of native perennial grass cover in 1991-1994, was above average in the west-central area, and indexes of livestock grazing levels were similar in the west-central and adjacent strata. At the beginning of our study, the west-central stratum contained a higher percentage of shrubs than the other strata. The west-central stratum apparently provided adequate foraging opportunities for Prairie Falcons in the 1970s because density of falcon pairs per area of cliff was higher than in the other strata, and nesting success was similar to that in other strata during the 1970s. The west-central area experienced extensive shrub loss between 1979 and 1997, but the amount of loss was similar to that in other strata, and by 1997, the west-central stratum still had a higher percentage of shrubs than the other strata.

The single obvious factor distinguishing the west-central stratum is the presence of military training. There are no quantitative data on historical levels of military training, but the scope and nature of military training in the OTA changed in the early 1990s when the National Guard began upgrading existing training facilities and constructing additional ones (U.S. Bureau of Land Management 1988). Recent military training activities likely have interacted with fire and livestock grazing to create less than favorable foraging opportunities for falcons in the west-central stratum. Radio telemetry studies in the 1990s (Marzluff et al. 1997) showed that Prairie Falcons from the west-central area were less effective at obtaining Townsend's ground squirrels than falcons nesting in the west segment, particularly during drought years. Westcentral falcons flew over larger areas, spent less time at their nests, and delivered fewer ground squirrels to their nests than falcons from the west stratum (U.S. Dept. Interior 1996).

Military training could affect Prairie Falcon foraging efficiency in at least two ways. First, training activity could directly disturb foraging falcons and prevent them from securing adequate prey. Military training activity did have direct, short-term influences on Prairie Falcon foraging behavior, which were apparent primarily on days with intense military training (U.S. Dept. Interior 1996). These periods of intensive training were relatively infrequent and should not have affected the ability of Prairie Falcons to secure prey over the entire nesting season. However, disruption of foraging at a critical point in the nesting season could have resulted in nesting failures. Intensive military training in June and July also might interfere with the foraging efficiency and subsequent survival of post-fledging Prairie Falcons, but additional research would be needed to determine whether this occurs. In Wyoming, Prairie Falcons tolerated disturbances associated with low levels of oil development on their foraging areas (Squires et al. 1993).

Second, training activity could cause subtle habitat changes, which we were unable to measure, that might be detrimental to ground squirrel populations. The best indirect measure of habitat suitability, amount of native perennial grass cover, suggests that ground squirrels should be at above average levels in the westcentral stratum. Unfortunately, we do not have reliable landscape-level data on the relative abundance of ground squirrels in the four strata to confirm this. Long-term use of armored vehicles and short-term armored-vehicle tracking experiments in shrub and grass habitats in the OTA had no detectable effects on ground squirrel population dynamics (Van Horne and Sharpe 1998). However, tracked vehicles used during military training cause ground disturbances that result in habitat fragmentation and increased 
dominance by exotic annual plant communities (Knick and Rotenberry 1997). In addition, areas like the OTA's artillery impact area, which are subjected to repeated burning, are less likely to experience natural shrub regeneration than areas that have burned only once (U.S. Dept. Interior 1996). These altered habitats are not generally beneficial for Townsend's ground squirrels over the long-term (Yensen et al. 1992, Van Horne et al. 1997).

The west-central area also may be inherently less resilient to all forms of disturbance and less responsive to restoration efforts that land management agencies have tested so far. In 1979, shadscale communities, which support lower densities of ground squirrels than other habitats (U.S. Dept. Interior 1979, Smith and Johnson 1985), dominated large areas of the west-central stratum. By 1997, losses of sagebrush in the OTA, in combination with poor quality shadscale habitats south of the training area, may have left the west-central stratum with too few ground squirrels to support Prairie Falcon populations at levels we recorded in the 1970s.

Timing of habitat alteration also may be important. Although the total amount of shrub loss in the west-central stratum has been less than in the other strata, it occurred during a narrower window of time (1979-1994 versus pre-19791994 for the east and east-central and 19791997 for the west). The consequences of habitat loss may be more serious when it occurs rapidly. It also is possible that Prairie Falcons, like Golden Eagles (Aquila chrysaetos; Kochert et al., unpubl. data), respond to habitat alterations several years after they occur. Extensive fires in the west stratum occurred more recently (1995-1996) than in the west-central stratum. If west-central falcons are just now responding to habitat changes that occurred between 1979 and 1994, we might expect similar changes in the west stratum in future years.

Managers of the Snake River Birds of Prey NCA are facing serious challenges in their attempts to regulate land uses to protect and enhance raptor populations. They face equally difficult challenges as they try to repair cumulative damages caused by wildfire, drought, livestock grazing, and military training activity. Our data suggest that foraging areas in the west-central stratum have been most seriously compromised. If military training activity is affecting Prairie Falcons adversely, we do not yet understand the mechanisms that might be involved. Although we have been unable to isolate a single causal mechanism for more pronounced population declines in the west-central stratum, it appears that the west-central stratum is the area most in need of rest and restoration. Continued and expanded monitoring of Prairie Falcon populations and their prey throughout the entire NCA will be helpful in distinguishing influences of individual land uses and habitat perturbations. However, because land uses and habitat perturbations act both synergistically and cumulatively, it is unlikely that we will ever find a single cause for declines in Prairie Falcon abundance and productivity. A continuing decline in number of nesting pairs and a possibly permanent reduction in the area's carrying capacity for Prairie Falcons would be inconsistent with goals of the legislation that established the NCA. Managers of the NCA should aggressively suppress wildfires, actively restore native shrubs and perennial grasses, and regulate existing land uses within Prairie Falcon foraging areas. Subsequent monitoring, integrated at all three trophic levels, will be necessary to determine whether land use restrictions and habitat recovery/restoration can reverse population declines. Management actions should be coordinated closely with monitoring efforts in an adaptive management approach (Lancia et al. 1996) to determine whether restrictions and restoration efforts are achieving desired results.

\section{ACKNOWLEDGMENTS}

This paper is a contribution from the Snake River Field Station, Forest and Rangeland Ecosystem Science Center, Biological Resources Division, U.S. Geological Survey. This study began as part of an investigation that led to establishing the Snake River Birds of Prey NCA; more recently it became part of the U.S. Bureau of Land Management and Idaho Army National Guard cooperative research project. We are indebted to more than 100 biologists and technicians who helped to collect data in the field. Data collection has been coordinated by three different agencies: first and primarily the Bureau of Land Management, then the National Biological Service, and most recently the Biological Resources Division of the U.S. Geological Survey. A. R. Bammann and J. H. Doremus played a key role in collecting data in the early years of the study. We thank J. M. Marzluff, M. S. Vekasy, L. S. Schueck, and all Greenfalk Consultant personnel for their cooperation in the 1990 s. We are grateful for the opportunity to use unpublished data on prey and habitat collected by several investigators: G. W. Smith, N. C. Nydegger, D. L. Quinney for the 1979 vegetation map; N. C. Nydegger, D. L. Johnson, and B. Van 
Horne for data on ground squirrels; and S. T. Knick and S. E. Watts for data on vegetation and livestock use in the 1990s. Special thanks go to G. R. Griggs, W. D. Dyer, and E. E. Black for logistical support and coordination, to the U.S. Fish and Wildlife Service, Snake River Basin Office for the loan of a jet boat, to G. S. Olson who analyzed juvenile ground squirrel data, to T. J. Zarriello for GIS analyses, and to D. M Parrish for data automation. We are indebted to S. T. Knick, J. T. Rotenberry, and B. Van Horne for helpful advice and discussions and for reviewing a draft of this manuscript. J. Squires and an anonymous reviewer also provided comments that improved the manuscript. Funding for this study was provided primarily by the Bureau of Land Management from 1974-1989 and by the Idaho Army National Guard through W. S. Seegar, U.S. Army Chemical Research and Engineering Center from 1990-1994. The National Biological Service and the Biological Resources Division of the U.S. Geological Survey provided additional funding and support from 1994-1997.

\section{LITERATURE CITED}

BECHARD, M. J. 1982. Effect of vegetative cover on foraging site selection by Swainson's Hawk. Condor 84:153-159.

Cytel Software Corporation. 1989. StatXact statistical software for exact nonparametric inference. Cytel Software Corporation, Cambridge, MA.

Dunstan, T. C., J. H. HARPER, AND K. B. PHIPPS. 1978. Habitat use and hunting strategies of Prairie Falcons, Red-tailed Hawks, and Golden Eagles. U.S. Dept. Int., Bur. Land Manage., Denver Federal Center, Denver, CO.

Galushin, V. M. 1974. Synchronous fluctuations in populations of some raptors and their prey. Ibis 116:127-134.

Johnson, D. R., N. C. NydegGer, AND G. W. SMith. 1987. Comparison of movement-based density estimates for Townsend ground squirrels in southwestern Idaho. J. Mammal. 68:689-691.

HolthuiJzen, A. M. A. 1990. Prey delivery, caching, and retrieval rates in nesting Prairie Falcons. Condor 92:475-484.

KNICK, S. T., AND J. T. RotenBERRY. 1997. Landscape characteristics of disturbed shrubsteppe habitats in southwestern Idaho (U.S.A.). Landscape Ecol. 12: 287-297.

KNICK, S. T., J. T. RotenberRy, AND T. J. ZARRIELlo. 1997. Supervised classification of Landsat thematic mapper imagery in a semi-arid rangeland by nonparametric discriminate analysis. Photogrammetric Engineering and Remote Sensing 63:6986.

Kochert, M. N., AND M. Pellant. 1986. Multiple use in the Snake River Birds of Prey Area. Rangelands 8:217-220.

KORPIMÄKI, E. 1984. Population dynamics of birds of prey in relation to fluctuations in small mammal populations in western Finland. Annal. Zool. Fenn. 21:287-293.

Kostrzewa, R., AND A. Kostrzewa. 1990. The relationship of spring and summer weather with density and breeding performance of the buzzard $\mathrm{Bu}$ - teo buteo), goshawk (Accipiter gentilis) and kestrel (Falco tinnunculus). Ibis 132:550-559.

KostrzewA, R., AND A. KostrzewA. 1991. Winter weather, spring and summer density, and subsequent breeding success of Eurasian Kestrels, Common Buzzards, and Northern Goshawks. Auk 108:342-347.

lancia, R. A., C. E. Braun, M. W. Collopy, R. D. Dueser, J. G. Kie, C. J. Martinka, J. D. Nichols, T. D. Nudds, W. R. Porath, AND N. G. Tilghman. 1996. ARM! For the future: adaptive resource management in the wildlife profession. Wildl. Soc. Bull. 24:436-442.

Marzluff, J. M., B. A. Kimsey, L. S. Schueck, M. E. McFadzen, M. S. VeKasy, AND J. C. Bednarz. 1997. The influence of habitat, prey abundance, sex, and breeding success on the ranging behavior of Prairie Falcons. Condor 99:567-584.

McFADZEN, M., AND J. M. MARZLUfF. 1996. Mortality of Prairie Falcons during the fledgling dependence period. Condor 98:791-800.

MoRITSCH, M. Q. 1983. Photographic guide for aging nestling Prairie Falcons. U.S. Dept. Int., Bur. Land Manage., Boise, ID.

NewTon, I., AND M. MARQUiss. 1982. Fidelity to breeding area and mate in Sparrowhawks. J. Anim. Ecol. 54:241-253.

OGDEN, V. T. 1973. Nesting density and reproductive success of the Prairie Falcon Falco mexicanus in southwestern Idaho. M.Sc. thesis, Univ. Idaho, Moscow, ID.

Olsen, P. D., AND J. Olsen. 1989. Breeding of the Peregrine Falcon Falco peregrinus: III. weather, nest quality and breeding success. Emu 89:6-14.

Runde, D. E. 1987. Population dynamics, habitat use and movement patterns of the Prairie Falcon ( $\mathrm{Fal}$ co mexicanus). Ph.D. diss., Univ. Wyoming, Laramie, WY.

SMITH, G. W., AND D. R. Johnson. 1985. Demography of a Townsend ground squirrel population in southwestern Idaho. Ecology 66:171-178.

SMITH, D. G., AND J. R. MURPHY. 1979. Breeding responses of raptors to jackrabbit density in the eastern Great Basin desert of Utah. Raptor Res. 13: $1-14$.

SMith, D. G., J. R. MuRPhy, AND N. D. Woffinden. 1981. Relationships between jackrabbit abundance and ferruginous hawk reproduction. Condor 83:52-56.

SPSS, INC. 1997. SYSTAT 7.0 for Windows. SPSS Inc., Chicago.

Squires, J. R., S. H. Anderson, and R. OAKLEAF. 1993. Home range size and habitat-use patterns of nesting Prairie Falcons near oil developments in northeastern Wyoming. J. Field Ornithol. 64:1-10.

STEENHOF, K. 1987. Assessing raptor reproductive success and productivity, p. 157-170. In B. A. Giron Pendleton, B. A. Millsap, K. W. Cline, and D. M. Bird [eds.], Raptor management techniques manual. Natl. Wildl. Fed., Washington, DC.

SteENHOF, K. 1998. Prairie Falcon (Falco mexicanus). In A. Poole and F. Gill [eds.], The birds of North America, No. 346. The Academy of Natural Sci- 
ences, Philadelphia and the American Ornithologists' Union, Washington, DC.

STEENHOF, K., AND M. N. KocherT. 1982. An evaluation of methods used to estimate raptor nesting success. J. Wildl. Manage. 46:885-893.

STEENHOF, K., AND M. N. KocherT. 1988. Dietary responses of three raptor species to changing prey densities in a natural environment. J. Anim. Ecol. 57:37-48.

STEENhof, K., M. N. Kochert, AND T. L. MCDonald. 1997. Interactive effects of prey and weather on Golden Eagle reproduction. J. Anim. Ecol. 66: 350-362.

U.S. Bureau of Land Management. 1988. Final environmental assessment land report, Idaho Army National Guard, Orchard Training Area Multipurpose Range Complex. Bruneau Resource Area, Boise, ID.

U.S. DEPARTMENT OF THE INTERIOR. 1979. Snake River Birds of Prey Special Research Report to the Secretary of the Interior. Bur. Land Manage., Boise, ID.

U.S. DEPARTMENT OF THE INTERIOR. 1995. Snake River Birds of Prey National Conservation Area management plan. Bur. Land Manage., Bruneau Res. Area, Lower Snake River District Office, Boise, ID.
U.S. DePartMent OF THE INTERIOR. 1996. Effects of military training and fire in the Snake River Birds of Prey National Conservation Area. BLM/ IDARNG Research Project Final Report. U.S. Geol. Surv., Biol. Res. Div., Snake River Field Sta., Boise, ID.

Van Horne, B., G. S. Olson, R. L. Schooley, J. G. CORN, AND K. P. BURnhaM. 1997. Effects of drought and prolonged winter on Townsend's ground squirrel demography in shrubsteppe habitats. Ecol. Monogr. 67:295-315.

Van Horne, B., R. L. Schooley, and P. B. Sharpe. 1998. Influence of habitat, sex, age, and drought on the diet of Townsend's ground squirrels, Spermophilus townsendii. J. Mammal. 79:521-537.

VAN Horne, B., AND P. B. Sharpe. 1998. Effects of tracking by armored vehicles on Townsend's ground squirrels in the Orchard Training Area, Idaho. Environ. Manage. 22:617-623.

Vekasy, M. S., J. M. Marzluff, M. N. Kochert, R. N. LehMAN, AND K. STEEnHOF. 1996. Influence of radio transmitters on Prairie Falcons. J. Field Ornithol. 67:680-690.

Yensen, E., D. L. Quinney, K. Johnson, K. TimmeRMAN, AND K. STEENHOF. 1992. Fire, vegetation changes, and population fluctuations of Townsend's ground squirrels. Am. Midl. Nat. 128:299312. 